DOI: $10.15290 /$ bsp.2019.24.02.10

Bartosz Targański

Warsaw School of Economics (SGH)

btarga@sgh.waw.pl

ORCID ID: https://orcid.org/0000-0002-5338-3936
Received: 14.01.2019

Accepted: 05.03.2019

\title{
Judicial Review of Decisions Relating to Inspections of the President of the Polish Office of Competition and Consumer Protection - Between the Judgment of the European Court of Human Rights
} in Case Delta Pekárny v. The Czech Republic and the Judgement of the Polish Constitutional Tribunal of 16 January 2019 in Case P 19/17

\begin{abstract}
The article discusses a recent legal change in relation to inspections conducted by the Polish Office of Competition and Consumer Protection (the "OCCP") in light of the standards of procedural safeguards that should be available to companies during inspections of competition authorities as described by the European Court of Human Rights (the "ECtHR") in case Delta Pekárny v. the Czech Republic. During inspections the OCCP could obtain access to documents unrelated to the subject of the proceedings, including private documents. This may lead to the infringement of the right to respect for private and family life protected under Article 8 of the European Convention on Human Rights (the "Convention"). In light of the Delta Pekárny judgment, decisions about the initiation of the inspection of competition authorities should be subject to effective judicial review. The judicial review should take place either prior to inspection or thereafter (ex post facto). The goal of the article is to verify the consistency of procedural safeguards during controls and searches conducted by the OCCP with the standards of protection in the Delta Pekárny judgement.
\end{abstract}

Keywords: right to privacy, competition law, controls, searches, judicial review

\section{Introduction}

The Convention sets the standards for human rights protection in Convention States. The impact of the ECtHR's judgments is not limited to the parties of a dispute 
only. According to the Interlaken Declaration from 2010, implementation of the Convention at the national level should inter alia include that Convention States take into account the ECtHR's developing case law, also with a view to considering the conclusions to be drawn from a judgment finding a violation of the Convention by another State, where the same problem of principle exists within their own legal system. ${ }^{1}$

This article discusses a recent legal change in relation to inspections conducted by the OCCP in light of the standards of procedural safeguards during inspections of competition authorities in the ECtHR's judgment in case Delta Pekárny v. the Czech Republic. ${ }^{2}$ As a result of the judgment of the Polish Constitutional Tribunal (the "PCT") of 16 January 2019, entrepreneurs may appeal the decisions of the Court of Competition and Consumer Protection (the "CCCP") expressing consent for searches.

\section{Major aspects of proceedings before the ECtHR relating to inspections of competition authorities}

According to Article 8 par. 1 of the Convention, everyone has the right to respect for his private and family life, his home and his correspondence. According to Article 8 par. 2, there shall be no interference by a public authority with the exercise of this right except such as is in accordance with the law and is necessary in a democratic society in the interests of national security, public safety or the economic well-being of the country, for the prevention of disorder or crime, for the protection of health or morals, or for the protection of the rights and freedoms of others.

According to established case law of the ECtHR the right to respect for private and family life, home and correspondence is applicable also to professional and business activities. In the judgement Niemietz v. Germany relating to the search of a lawyer's office in the course of criminal proceedings, the ECtHR argued that the exclusion of professional or business activities from the notion of "private life" is not warranted by any reason of principle and could lead to inequality of treatment under Article $8 .^{3} \mathrm{In}$

1 High Level Conference on the Future of the European Court of Human Rights, Interlaken Declaration 19 February 2010, point B.4.c, available at: https://www.echr.coe.int/ Documents/2010_Interlaken_FinalDeclaration_ENG.pdf (accessed 20.05.2019).

2 The ECtHR judgment of 2 October 2014 in case Delta Pekárny A.S. v. the Czech Republic, no. $97 / 11$.

3 See $₫ 29$ of the ECtHR judgment in case Niemietz v. Germany, 16 December 1992 (no.13710/88): "There appears, furthermore, to be no reason of principle why this understanding of the notion of "private life" should be taken to exclude activities of a professional or business nature since it is, after all, in the course of their working lives that the majority of people have a significant, if not the greatest, opportunity of developing relationships with the outside world. This view is supported by the fact that, as was rightly pointed out by the Commission, it is not always possible to distinguish 
Judicial Review of Decisions Relating to Inspections of the President of the Polish Office...

effect, the notion of "home" in the meaning of Article 8 covers not only private places of residence, but also the registered office of a company run by a private individual, as well as a legal person's registered office, branches and other business premises. ${ }^{4}$ However, with respect to inspections in commercial premises, the interference of public authorities can be wider than in the case of private premises, provided that the rules and practice of using them ensure adequate, effective protection against fraud. ${ }^{5}$

The analysis of the ECtHR under Article 8 in relation to the inspection of the public authorities is aimed at determining, whether the inspection is "necessary in a democratic society" and whether the legislation and administrative practice relating to inspections of competition authorities provide sufficient safeguards to prevent arbitrary measures of administration affecting the right to privacy.

In the light of the case law of the ECtHR, inspections of competition authorities could be justified by the protection of public safety or the economic well-being of the country. In case Debut Zrt. and others v. Hungary the ECtHR argued that "the measures complained of [a dawn raid - added by author] were indisputably lawful and pursued the legitimate aim of ensuring the "economic well-being of the country" by combating cartel practices. An unannounced court ordered search of the suspected companies' business premises must be seen as an appropriate measure to collect evidence, without which the authorities had virtually no chance to unveil those activities."

\section{Findings of the ECtHR in the Delta Pekárny judgment}

In the Delta Pekárny judgement the ECtHR was concerned with the application of Article 8 of the Convention to the inspection conducted by the Czech Competition Authority (the "Czech Authority") at the premises of Delta Pekárny A.S. (the "Delta" or "Company"), a bakery company from the Czech Republic. The Czech Authority suspected Delta and two other companies for price collusion of bakery products. For

clearly which of an individual's activities form part of his professional or business life and which do not. Thus, especially in the case of a person exercising a liberal profession, his work in that context may form part and parcel of his life to such a degree that it becomes impossible to know in what capacity he is acting at a given moment of time".

4 See, inter alia, the ECtHR judgment of 15 February 2011 in case Heino v. Finland, no. 56720/09, $\$ 31$; the ECtHR judgment of 28 April 2005 in case Buck v. Germany, no. 41604/98, $\$ 31$; the ECtHR judgement of 30 March 1989 in case Chappell v. the United Kingdom, $\$ \$ 26$ and 51; the ECtHR judgment of 16 December 1992 in case Niemietz v. Germany, $\$ \$ 29-31$; the ECtHR judgment of 6 April 2002 in case Société Colas Est and Others v. France, no. 37971/97, $\$ \$ 40-41$.

5 The ECtHR judgment of 16 December 1992 in case Niemietz v. Germany, \$31; the ECtHR judgment of 6 April 2002 in case Société Colas Est and Others v. France, no. 37971/97, \$\$ 48-49.

6 The ECtHR judgment of 20 November 2012 in case Debút Zrt. and Others v. Hungary, no. 24851/10, \$3; the ECtHR judgment of 21 December 2010 in case Groupe Canal Plus and Sport Plus v. France, no. 29408/08, \$\$ 54-55. 
that reason, the Czech Authority inspected the offices of Delta in Brno and Prague on 19 November 2003. On this day the Czech Authority's officials handed in to the representatives of Delta a notice on the initiation of the proceedings indicating the subject-matter of the proceedings (the "Notice"). The Notice was signed by the senior director of the Czech Authority and was accompanied by an authorization with the names of officials empowered to conduct the onsite inspection. The Notice was not reviewed by the court.

The inspection mainly consisted in reviewing and making copies of email correspondence of Delta's selected managers. However, some managers declined to cooperate with the officials. In particular, the CEO prevented the officials from reading his e-mail correspondence contained in his notebook, took away the notebook and left the premises of the company, while another manager took away from the officials two printed e-mails that had been previously handed over to them on the ground that they represented private correspondence. ${ }^{7}$ As a result, the Czech Authority issued a decision to impose a fine of CZK 300,000 (ca. EUR 11,500) on Delta for obstructing the inspection. Later, the Czech Authority issued a decision finding an agreement restricting competition and imposing a penalty of CZK 55 million (ca. EUR 2.1 million).

Delta appealed the decisions to the antimonopoly authority, then before the Regional Court in Brno, the Czech Supreme Administrative Court and subsequently before the Czech Constitutional Court. Delta questioned the legality of obtaining evidence during the inspection and the legitimacy of its execution. According to the Company, an inspection without the prior authorization of the court and effective control by an independent authority violated the Czech Constitution and Article 8 of the Convention. It referred to the standards established in the ECtHR case law $^{8}$ according to which judicial authorization prior to inspection and effective independent supervision of the Czech Authority's actions should have been available. The Czech Authority and courts rejected the appeals arguing that the inspection was lawful and that Czech law provided entrepreneurs sufficient measures to challenge the very fact of the inspection and the way in which it had been carried out. ${ }^{9}$

In the Delta Pekárny judgement the ECtHR argued that in the absence of prior consent of a court to conduct an inspection by the competition authority, the protection of individual rights resulting from the initiation of the control that is not

7 R. Barinka, The Czech Constitutional Court rules that inspection at business premises of a company does not require a prior judicial authorization (Delta Pekarny), 26 August 2010, e-Competitions Bulletin August 2010, Art. N 33217, available at: https://www.concurrences.com/ en/bulletin/news-issues/august-2010/The-Czech-Constitutional-Court (accessed 20.05.2019).

8 The ECtHR judgment of 6 April 2002 in case Société Colas Est and Others v. France, no. 37971/97.

$9 \$ 19$ of the ECtHR judgment of 2 October 2014 in case Delta Pekárny A.S. v. Czech Republic, no. 97/11. 
Judicial Review of Decisions Relating to Inspections of the President of the Polish Office...

disproportionate and justified, should be guaranteed by ex post judicial review. ${ }^{10}$ It found that under the Czech law the competition authorities were entitled to conduct inspections in order to verify the existence of evidence of suspected antimonopoly practice, but the existing legal measures did not allow companies to judicially review the very fact of initiation of inspection neither ex ante nor ex post. ${ }^{11}$ The ECtHR took into consideration, firstly, that the notification of the inspection was authorized by the senior director of the Czech Authority. ${ }^{12}$ Secondly, the notice initiating the inspection did not precisely state either the facts or the evidence on which the presumptions of anti-competitive practices were based..$^{13}$ Thirdly, two appeal proceedings initiated by Delta before national courts focused on the amount of the fine imposed for the obstruction of the inspection and on substantive finding of the Czech Authority that Delta was party to anti-competitive practice.

In effect, the violation of Article 8 was found by the ECtHR, as national courts did not conduct a sufficient judicial review of the arbitrariness of the inspection. ${ }^{14}$ In other words, the national courts did not review the reasons for initiation of the inspection, its duration, goal, scope and necessity. ${ }^{15}$ Hence the intervention into Delta's rights protected under Article 8 cannot be considered as proportionate to the legitimate goal. ${ }^{16}$

\section{Inspections of the Polish competition authority}

According to the Delta Pekárny judgement protection of the right to privacy requires that companies have effective measures to challenge the reasons and proportionality of inspections of competition authorities. The effective review measures should be provided either before the inspection in the form of judicial authorization or ex post facto. The effective review consists in the assessment of the scope, the duration of the inspection, along with its necessity and proportionality. From this perspective I will review below the quality of the existing review measures for inspections conducted by the Polish competition authority, i.e. the OCCP.

As a starting point it should be noted that the Polish Act on Competition and Consumer Protection (the "Polish Act") distinguishes between two types of inspections: controls (pl: kontrole) and searches (pl: przeszukania). In both types the OCCP can look for the same types of documents. Both types of investigations are

$\begin{array}{ll}10 & \text { Id. } \$ 93 . \\ 11 & \text { Id. } \$ \$ 86-91 . \\ 12 & \text { Id. } \$ 85 . \\ 13 & \text { Id. } \$ 85 . \\ 14 & \text { Id. } \$ 93 . \\ 15 & \text { Id. } \$ 87, \$ 91 . \\ 16 & \text { Id. } \$ 93 .\end{array}$


authorized by the OCCP's President but a prior consent of the court, i.e. the CCCP, is required for searches, but not for controls. Both, the authorization of the OCCP's President to conduct the control and the CCCP's decision consenting to conduct the search are handed in by the OCCP's officers to the representatives of the company at the beginning of the inspection.

From the formal perspective the control should be based on "cooperation" between the OCCP and the company, i.e. the OCCP's officers can ask for the documents to be made accessible to them, but they cannot search for the documents themselves. Whereas during the searches, the OCCP's officers can search for the documents themselves. In practice, the legal position of inspected companies is basically the same in the case of obstruction. Firstly, the OCCP may always switch from "cooperative" control to forced searches, if, in its view the company does not sufficiently cooperate. Secondly, in both types of inspections the OCCP's officers may be assisted by the police, which creates an obvious pressure on the staff of the company to "cooperate". Thirdly, in both cases the OCCP may impose a penalty of up to EUR 50 million on the company. In light of this it seems obvious that the prior judicial authorization of the CCCP should be ensured for both types of inspections, not only for searches. ${ }^{17}$

\section{Prior judicial review under the Polish law}

As regards controls, under the Polish Act the authorization of the OCCP's President to conduct the control does not indicate the evidence or even suspicion which substantiates the decision to initiate the procedure. Likewise, the OCCP's President does not require the consent of the CCCP to authorize the control to be conducted. In addition, inspected company may not appeal such authorization, which is even not a formal decision.

In light of the Delta Pekárny judgement, facts justifying the initiation of the inspection need to be verified by courts and the necessity of inspection cannot be proven by the evidence collected during the inspection. ${ }^{18}$ In this respect, the

17 Turno B., Wardęga E., Uprzednia i następcza kontrola aktów upoważaniających organ ochrony konkurencji do przeprowadzenia niezapowiedzianej kontroli (przeszukania) przedsiębiorcy. Glosa do wyroku Europejskiego Trybunału Praw Człowieka z 2 października 2014 r. w sprawie Delta Pekárny przeciwko Republice Czeskiej, internetowy Kwartalnik Antymonopolowy i Regulacyjny, 2015, nr 8(4), p. 117.

18 M. Bernatt, Between Menarini and Delta Pekarny - Strasbourg view on intensity of judicial review in competition law. [in] The procedural aspects of the application of competition law: European frameworks - Central European perspectives, Csongor István Nagy (ed.), Europa Law Publishing, Gröningen, 2016, p. 8, available at: https://www.academia.edu/26014468/Between_Menarini_ and_Delta_Pekarny_Strasbourg_view_on_intensity_of_judicial_review_in_competition_law (accessed 20.05.2019). 
Judicial Review of Decisions Relating to Inspections of the President of the Polish Office...

authorization of the OCCP's President to conduct searches indeed requires prior consent of the CCCP. ${ }^{19}$ However, the decisions of the CCCP have not, until recently (see following section), been subject to appeal. In the absence of two instance proceedings a very rigorous examination of the OCCP's notion for conducting a search is required, ${ }^{20}$ i.e. the CCCP should investigate whether the OCCP has actually proved the necessity to carry out a search. ${ }^{21}$ In practice, there are doubts with respect to the thoroughness of the CCCP's review. Firstly, copies of the OCCP's application for the CCCP's consent are not added to the administrative file. Secondly, the CCCP's consent for searches does not include justification. In effect, the evidence or suspicion which substantiate the search remains unknown to the companies. Thirdly, searches were conducted by the OCCP also in relation to vertical agreements, where the evidence can usually be obtained in the course of simple requests for information without initiating formal proceedings. ${ }^{22}$ As rightly pointed out by B. Turno and E. Wardęga, one can therefore argue, that the effectiveness of the consent procedure is rather illusionary. ${ }^{23}$

\section{Judgement of the Polish Constitutional Tribunal of 16 January 2019 in case $P$ 19/17}

The above assessment may however change soon as a result of the judgement of the PCT of 16 January 2019. ${ }^{24}$ The PCT argued that provision that makes it impossible to appeal the decision of the CCCP on consenting to an OCCP search (i.e. second sentence in art. 105n par. 4 of the Polish Act) is not compliant with the Polish Constitution, because it completely deprives entrepreneurs of the right to court. The complaint referred directly to the Delta Pekárny ruling, which was followed by the PCT. The PCT stressed that the inability to appeal, concerns searches which deeply interfere with the sphere of the entrepreneur's rights. Activities undertaken during searches by the antimonopoly authority violate the freedom of economic activity, the

19 Art. 105n par. 2 of the Polish Act.

20 M. Bernatt, Sprawiedliwość proceduralna w postępowaniu przed organem ochrony konkurencji, Wydawnictwo Naukowe Wydziału Zarządzania Uniwersytetu Warszawskiego, Warszawa 2011, p. 227.

21 M. Bernatt, Ustawa o ochronie konkurencji i konsumentów. Komentarz. T. Skoczny (ed.), 2 issue, Warszawa 2014, Legalis.

22 Art. 50 of the Polish Act.

23 Turno B., Wardęga E., Uprzednia i następcza kontrola...op. cit., p. 114.

24 Judgement of the Polish Constitutional Tribunal of 16 January 2019 in case P 19/17, Official Journal of 22 January 2019, pos. 128. The judgement was issued in response to the legal question of the Appellate Court in Warsaw of 22 August 2017, considering the complaint a company against the CCCP decision rejecting the complaint against the CCCP's decision agreeing to conduct a search in the premises of that company. 
right to privacy and property rights to a greater extent than in the case of standard controls carried out by other authorities. Considering the substantial nature of those rights and freedoms, such a construction of the procedure that completely excludes one party from presenting arguments before court, is incompatible with art. 45 par. 1 of the Polish Constitution. In the opinion of the PCT, in light of the nature of interference a balance between the effectiveness of the proceedings and the rights of defence is required. The balance should protect against arbitrary interference in the sphere of private entrepreneurial activity and disproportional control activities. ${ }^{25}$

The PCT followed the argumentation of the Appellate Court that the content of this provision leads to gross disproportion of the parties procedural positions: "If the OCCP's application for consent to a search is dismissed, despite the lack of the opportunity to challenge the CCCP's decision, it may reapply by presenting new arguments. On the other hand, the entrepreneur whose premises are to be inspected, does not take part in the pre-consent proceedings. The decision is issued in closed session without informing the entrepreneur about the court seating. What's more, if the OCCP's application is accepted, the entrepreneur has no possibility of appeal against the ruling, which in turn closes him the opportunity to present his position not only before second instance court, but in the course of the proceedings. In other words, by depriving the entrepreneur of the right to lodge a complaint, the entrepreneur is completely deprived of the right to court, and has no option to present his arguments. In this way the legislator violated the foundation of the right to court - the right to be heard. Searched entrepreneur, in the case of a positive court decision, is presented with a fait accompli." ${ }^{26}$

As a result of the PCT's judgement appeals from the CCCP's decisions expressing consent to a search will be allowed under Article $394 \$ 1$ of the Polish Code of Civil Procedure.

\section{Ex post facto judicial review under the Polish law}

As regards controls under Polish law, companies may file objections (pl: sprzeciw) to the initiation and exercise of control by the OCCP. ${ }^{27}$ The objections are filed to the OCCP within three working days from the day on which the control was initiated or from the day it came to procedural breach in relation to the delivery and the content of authorizations to perform control activities as well as in relation to persons

25 Statement of the Polish Constitutional Tribunal available at: http://trybunal.gov.pl/postepowaniei-orzeczenia/komunikaty-prasowe/komunikaty-po/art/10461-ustawa-o-ochronie-konkurencjii-konsumentow/ (accessed 20.05.2019).

26 Legal question of the Appellate Court of 22 August 2017 to the Polish Constitutional Tribunal in case P 19/17 available at: https://ipo.trybunal.gov.pl/ipo/view/sprawa.xhtml? \&pokaz=dokumenty\&sygnatura=P\%2019/17 (accessed 20.05.2019). 
Judicial Review of Decisions Relating to Inspections of the President of the Polish Office...

participating in the control. These aspects are of minor importance for the protection of companies' interest. Objection may also be filed in case control activities go beyond the scope indicated in the authorization. ${ }^{28}$ The practical importance of this provision seems also rather doubtful, as the scope of control can be described only in a general way, which is typical for suspected infringements of competition law. In fact, by filing objections companies cannot challenge the essential aspects of the control, i.e. its justification and the proportionality of inspections. ${ }^{29}$

Inspected companies may also appeal to the CCCP, if the activities of the OCCP go beyond the scope of the control given in the OCCP's authorization (for controls ${ }^{30}$ ) or in the consent given by the court (for searches ${ }^{31}$ ) or if other control (or search) activities have violated the law. Similarly, to objections, the scope of those complaints is limited to violation of the conditions of controls and searches only, not the very fact of their conduct. ${ }^{32}$

Significant weakness in privacy protection can be indicated also with respect to the handling of private documents found during inspections conducted by the OCCP. If private documents are found during search activities, the officials of the OCCP should send them, without reading them, to the prosecutor or court in a sealed envelope. ${ }^{33}$ Surprisingly, according to the literal wording of Polish law, the envelope procedure applies only to documents identified during searches but not during control activities. This does not seem rational given the fact that the OCCP has access to the same documents in both types of inspections.

It seems also that an appeal from the OCCP's final decision stating an infringement of competition law and imposing a fine does not guarantee full judicial review of the inspection. ${ }^{34}$ Firstly, such decisions in antimonopoly cases are usually issued after 2-3 years or later, which is further prolonged by the appeal procedure. Secondly, the evidence found in their course is usually an important basis for finding the alleged practice and imposing a fine. As the finding of the OCCP are in the public domain not only by virtue of the decision but also by way of press releases, companies are exposed not only to antitrust fines, but also civil claims related to antitrust infringements and reputational damages. Even if the decision is eventually lifted

28 Art. 49 par. 9 in connection with art. art. 59 par. 1 of the Law of Entrepreneurs.

29 See G. Materna, Warunki podejmowania kontroli i przeszukań w postępowaniach z zakresu ochrony konkurencji prowadzonych na podstawie ustawy o ochronie konkurencji i konsumentów w aspekcie orzecznictwa na tle art. $8 \mathrm{ETPCz}$, internetowy Kwartalnik Antymonopolowy i Regulacyjny 2015, nr 8(4), p. 16.

30 Art. $105 \mathrm{~m}$ par. 1 in connection with art. 105b par. 1 point 2 of the Polish Act.

31 Art. 105p of the Polish Act.

32 See B. Turno, E. Wardęga, Uprzednia i następcza kontrola...op.cit., p. 115.

33 Art. 105q of the Polish Act in connection with art. 225 par. 1 of the Polish Code of Penal Procedure.

34 Different view is presented by M. Sieradzka in comments to art. 105n [in] K. Kohutek, M. Sieradzka, Ustawa o ochronie konkurencji i konsumentów. Komentarz, LEX 2014. 
for procedural reasons, the company may not be able to fully compensate for the reputational damage incurred ${ }^{35}$ or losses related to participation in civil proceedings.

\section{Conclusions}

According to the Delta Pekárny ruling the right to privacy in the meaning of Article 8 of the Convention requires that companies should have effective measures to challenge the reasons and proportionality of inspections of competition authorities. The judicial review could be provided either before the inspection in the form of judicial authorization or ex post facto. The effective review consists in the assessment of necessity and proportionality of inspections. In the absence of such review mechanisms, inspections of competition authorities are likely to violate Article 8 of the Convention.

Polish law formally distinguishes between two types of inspections of competition authorities, i.e. controls and searches. For controls there are no measures guaranteeing sufficient judicial review, either before or ex post facto, of the initiation of control and its proportionality. As regards searches, the recent judgment of the Polish Constitutional Tribunal of 16 January 2019 has significantly improved the position of companies. Although the judgments of the ECtHR are binding only between the parties to the dispute, the judgment of the PCT is evidence of the direct influence of the Delta Pekárny judgment on the standards of inspections conducted by the OCCP. As a result of the PCT ruling entrepreneurs may appeal the CCCP's decisions expressing consent for searches. This legal tool may significantly improve the effectiveness of judicial review not only by allowing companies to appeal the CCCP's decisions but may also stimulate the CCCP for more thorough verification of the OCCP's justification for inspections.

As a result of the recent judgment of the Polish Constitutional Tribunal, there is wide divergence between possibilities to protect against the arbitrariness of the OCCP during controls and searches. From the perspective of the Delta Pekárny judgment, lack of effective judicial review for controls (prior or ex post facto) should be considered a major legal gap. It is therefore a de lege ferenda postulate either to supplement the controls with the same mechanisms of judicial review available for searches or to integrate controls and searches into one type of inspection.

More generally, considering the importance of the values protected under Article 8 of the Convention, the Delta Pekárny judgment should be further promoted as a conceptual framework for the assessment of inspections conducted by competition authorities. In the digital era, when competition authorities can copy vast sets of

See B. Turno, E. Wardęga, Uprzednia i następcza kontrola..., op.cit., p. 115. 
data, the risk of interference into right to privacy, is inevitable. This risk needs to be mitigated by the introduction of effective judicial review mechanisms.

\section{BIBLIOGRAPHY}

Barinka R., The Czech Constitutional Court rules that inspection at business premises of a company does not require a prior judicial authorization (Delta Pekarny), 26 August 2010, e-Competitions Bulletin August 2010, Art. $\mathrm{N}^{\circ}$ 33217, available at: https://www.concurrences.com/en/bulletin/ news-issues/august-2010/The-Czech-Constitutional-Court (accessed 20.05.2019).

Bernatt M., Between Menarini and Delta Pekarny - Strasbourg view on intensity of judicial review in competition law. [in] The procedural aspects of the application of competition law: European frameworks - Central European perspectives, Csongor István Nagy (ed.), Europa Law Publishing, Gröningen, 2016, available at: https://www.academia.edu/26014468/Between_ Menarini_and_Delta_Pekarny_Strasbourg_view_on_intensity_of_judicial_review_in_ competition_law (accessed 20.05.2019).

Bernatt M., Sprawiedliwość proceduralna w postępowaniu przed organem ochrony konkurencji, Wydawnictwo Naukowe Wydziału Zarządzania Uniwersytetu Warszawskiego, Warszawa 2011.

Bernatt M., Ustawa o ochronie konkurencji i konsumentów. Komentarz. T. Skoczny (ed.), 2nd edition, Warszawa 2014, Legalis.

High Level Conference on the Future of the European Court of Human Rights, Interlaken Declaration from 9. February 2010, available at: https://www.echr.coe.int/Documents/2010_Interlaken_ FinalDeclaration_ENG.pdf (accessed 20.05.2019).

Kohutek K., Sieradzka M., Ustawa o ochronie konkurencji i konsumentów. Komentarz, LEX 2014.

Materna G., Warunki podejmowania kontroli i przeszukań w postępowaniach z zakresu ochrony konkurencji prowadzonych na podstawie ustawy o ochronie konkurencji i konsumentów $\mathrm{w}$ aspekcie orzecznictwa na tle art. $8 \mathrm{ETPC}$, internetowy Kwartalnik Antymonopolowy i Regulacyjny, 2015, nr 8(4).

Turno B., Wardęga E., Uprzednia i następcza kontrola aktów upoważaniających organ ochrony konkurencji do przeprowadzenia niezapowiedzianej kontroli (przeszukania) przedsiębiorcy. Glosa do wyroku Europejskiego Trybunału Praw Człowieka z 2 października 2014 r. w sprawie Delta Pekárny przeciwko Republice Czeskiej, internetowy Kwartalnik Antymonopolowy i Regulacyjny, 2015, nr 8(4). 
